Original article

\title{
THE OTTOMAN INFLUENCES ON WEST TRIPOLI THROUGH FOUR INSCRIPTIONS PRESERVED IN ASSARAYA ALHAMRA'A MUSEUM
}

\author{
Khairallah, G. \\ Archaeology dept., Faculty of Arts, Tanta University \\ e-mail:dr_gamal1963@yahoo.com
}

\begin{abstract}
This study deals with the Ottoman Influences on Tripoli in Arts, such as decorations, Antiques, and inscriptions which need more studies. The research tries to show these influences through four inscriptions which are translated and published for the first time. Two of them were written in Turkish language. Many kinds of Ottoman scripts, like Thuluth, Alenstaliq and Tughra'a were used in these inscriptions. The research proved that the Ottomans have interested in religious and military buildings in West Tripoli. The decoration associated with the inscriptions has ottoman features, like Romi decoration, Lily flower, blooming flower, and the Ottoman flags. This research is considered an addition to the previous researches that studied the Ottoman influences on its subsidiaries states.
\end{abstract}

Keywords: Ottoman, Tripoli, Inscriptions, Thuluth, Alenstaliq, Tughra'a, Bab-Elbahr, Artillery

\section{Introduction}

The Ottoman conquest to Tripoli, in $958 \mathrm{AH} / 1551$ was only response to the residents of Tripoli call for help, as they called the Ottoman Empire because it was the largest Muslim country, and asked it to rescue them from the European crawl. The Ottoman state responded to their calls, it did not fight the people of that country, but they conquered to save the population from the dangers of eliminating their religion and nation [1], this happened in the reign of Sultan Suleiman the Magnificent, who sent Murad Agha, with a small force to the city of Tripoli, after that Murad Agha requested the supply of the Sultan, who sent naval and ground forces to strengthen his forces, led by Qoja Sinan Pasha al-Sadr the greatest who could penetrate the port and entered the city in $958 \mathrm{AH} /$ 1551AD [2]. The Ottoman presence in Tripoli (of the west) is divided into three historical periods, $1^{\text {st }}$ the period of the first Ottoman era from 958-1123 AH /1551-1711 AD. $2^{\text {nd }}$ the age of Alqurmanly from 1123-1251 AH /1711-1835 AD. $3^{\text {rd }}$ the period of the second Ottoman era from 1251-1330 AH / 1835-1911 AD. The main difference between these periods is that during the first and the second Ottoman eras, Tripoli was under the direct administration of the Ottoman State, the Governor (pasha) was sent from Istanbul, and during the Alqurmanly period, Tripoli was partial independent, as the pasha Alqurmanly should get a Royal Firman after his investiture as a ruler of the state [3]. The Ottoman state has followed a policy based on the lack of integration between the Turkish Ottomans, and the people of the States. Affiliation did not happen to 
these peoples. The use of Turkish language was limited to government bureaucracy, and was spoken only by Turkish. The result of that policy was that the Arab peoples maintained their language, culture, customs and traditions [4]. But there are some architectural and artistic elements that passed to Tripoli, whether by direct way by Ottoman Turkish residents, or by indirect way through Tunisia, which took some of the effects from Istanbul [1]. Tripoli was not a fertile ground for Islamic artistic development in spite of the spread of many artistic traditions since the opening of 'Amr ibn al-Aas' to it in 22AH/642AD, such as artistic traditions of Morocco, passing by the Moroccan which dominated Africa in the ages of Aghlabids 184-296 AH /800-909AD, and the Fatimids 297-357AH, then Almurabeteen 448-540 AH/1056-1147AD, After that Al-muwahdeen (524-667 AH/1130 -1269 AD), At last Beni Hafs $625-755$ AH [5]. As Tripoli was dependent on Tunisian style before the ottomans its architectural artistic heritage was surrounded by much mystery because of the lack of artistic features that distinguish them [6]. The four centuries of the Ottoman period in Tripoli have witnessed a mixture of local artistic and expatriate Ottoman traditions in the fields of arts and architecture. The Libyan Artistic production was reflection to the ottoman Artistic tradition. The rich men went with the approach of the governors, pashas and the seniors of the Ottoman administrative system. The degree of interest of the Artistic and decorative style was determining the position of the person to whom the masterpiece was made. The importance of the study of the inscriptions in Tripoli in the Ottoman period returns to being- undoubtedlyhistorical documents after losing most of the documents of Tripoli foundations in this period [7]. These inscriptions haven't been collected in an independent research before .The vast majority of the remained foundations in Tripoli had been constructed or reconstructed in the
Ottoman period. There is no alternative to the inscriptions of our study. Also these inscriptions are dating to different religious or defensive foundations. These inscriptions are important because they all are dated, and carry the names of its founders or restorers and their titles and jobs. Some of them may have played an important role in the Ottoman state, and then transferred the Ottoman influences in art and architecture. A scientific approach has been followed in this study which is based on two axes, the first axis: is the descriptive study in terms of the way in which the text is displayed, included with identifying sizes of the panel and accompanied by a translation of two Turkish inscriptions with the help of a specialist, and showing its Hejra date, and its corresponding date of the Christ, and clarifying the place that it was fetched from through returning to the documents of red palace museum in Tripoli. The second Axis is the analytical study, and it is divided into the first section: an analytical study of the form, which contains a study of raw material which the inscription is engraved on, and the ways of implementation, and the kinds of scripts used, and the accompanied decorations, and the language written by. The second section is the analytical study of the content of the inscriptions, which contains the study of names, titles and jobs that are mentioned and brief study about the foundations that these inscriptions dating to in addition to the method of dating used. I have recoursed -in the study of these inscriptions- to noting through field study and I have taken photos to the marble panels that contained these inscriptions, and I have made figures to the writings and decorations, and used some available resources. The resources refer in brief to the foundations that these inscriptions dating to, and sometimes it refers to the founders. One of the Arabic references is "Libya, the cities development and its urban planning" written by Ali Elmelody Amourah, Beirut, 1998. The Encyclopedia of 
Islamic monuments in Libya, Part.1, by Ramadan Shaqlouf and others, Antiquities foundation, 1980. The history of mosque architecture in Libya in the Ottoman and Alqurmanly period, by Ali Massoud Al-Balushi, The publication of the Islamic Call Society, Tripoli, 2007, some of the translated books are "Islamic architecture in Libya for the Italian Orientalist Ghaspry Messana, "Translated
Generation House, 1973, and The Ottoman influences on architecture and Islamic Arts in Libya, by Salah Albahnasy. The eighth conference of the code of Ottoman monuments in the world, Tunisia, 1998. In this previous research the author has dealt with some architectural examples and some decorative examples but didn't deal with inscriptions.

\section{by Ali Elsadiq Hassanein, The}

\subsection{The first section, descriptive study of the inscriptions}

1.1.1. The inscription of the restoration of Bab Al Bahr Tower, $1022 \mathrm{AH} / 1613$ AD., pl. \& fig. (1).
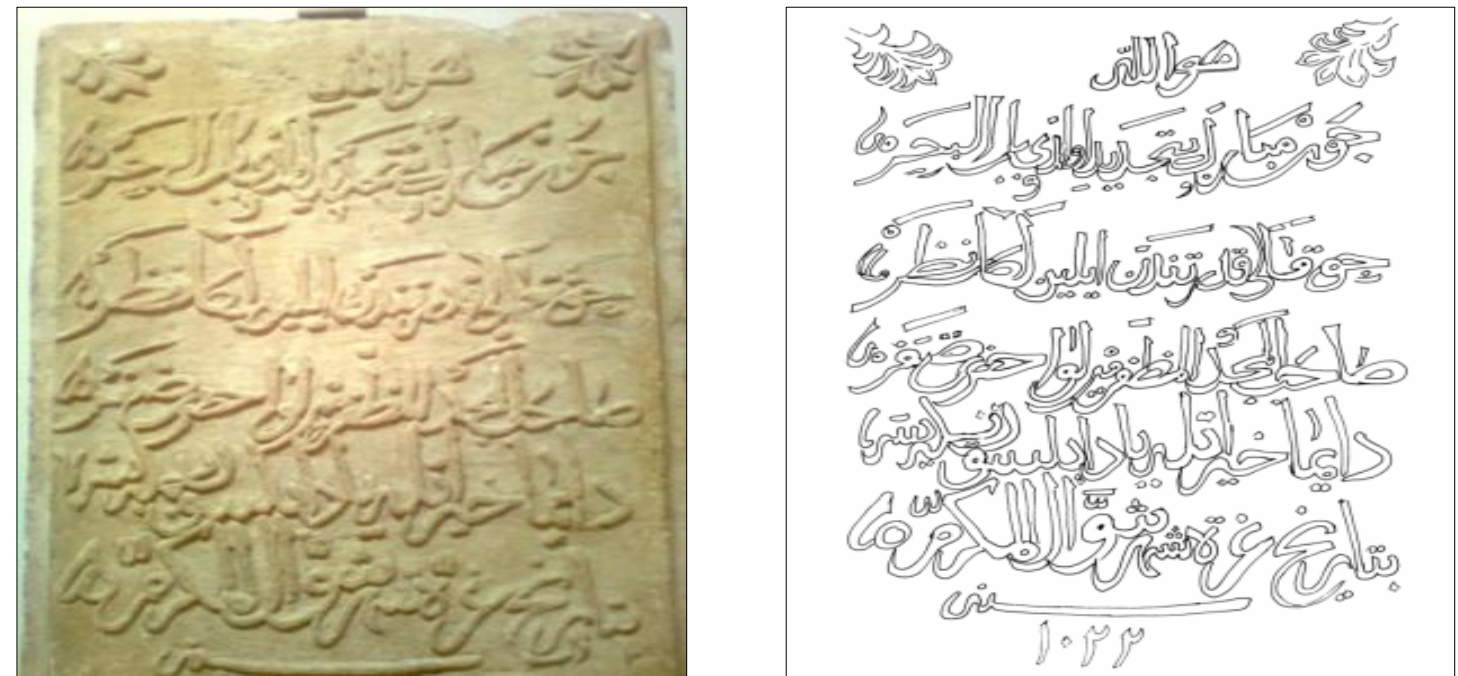

Plate \& Figure (1) renewal inscription of Bab Elbahr (1022 AH / 1613 AD)

It's an inscription written in Turkish language in seven lines with a relief Thuluth script on white marble panel measured $50 \times 60 \mathrm{~cm}$. Two brunches

\section{He is Allah. \\ Translation into English \\ With great happiness, the tower of $\mathrm{Bab} \mathrm{Al}$ Bahr has been renovated}

And thus the owner of the vineyard, is the one who made an eloquent effort.

He has triumphant glory, The Major General Prince Safar.

$\mathrm{He}$ will be always mentioned with his goodness, my Allah gives him all his wishes.

The initial of the honored lunar month of Shawwal.Year 1022 AH (1613 AD) ${ }^{[\mathrm{A}]}$. It's an inscription written in Arabic in eight lines in a relief Thuluth script on a white square marble panel, its side length is $50 \mathrm{~cm}$. It's the inscription of the of a plant were hanging from two angles at the top right and left of the engraving performed in a "Romi" style, the inscriptions:

\section{Turkish inscription}

$$
\begin{aligned}
& \text { هو الله. . (1) } \\
& \text { جور مبارك بتجديد أولدى برج بـاب البحر. } \\
& \text { جوقالى قدر تتدن إيلين لطاسـر نظـــر. } \\
& \text { صاحب المجد المظفر ميرلوا حضرت صفر. } \\
& \text { دايماً خير إليه يادا يلسون نيلـه يســر. } \\
& \text { بتاريخ شهر شو ال المكرم سنة بr • 1 }
\end{aligned}
$$

\subsubsection{The inscription of the Red Minaret Mosque( 1089 AH /1678 AD) pl. \& fig. (2)} renewal of Haj Ahmed Katkhoda to the mosque after his construction to it before the renewal of about 10 years, the inscription is: 

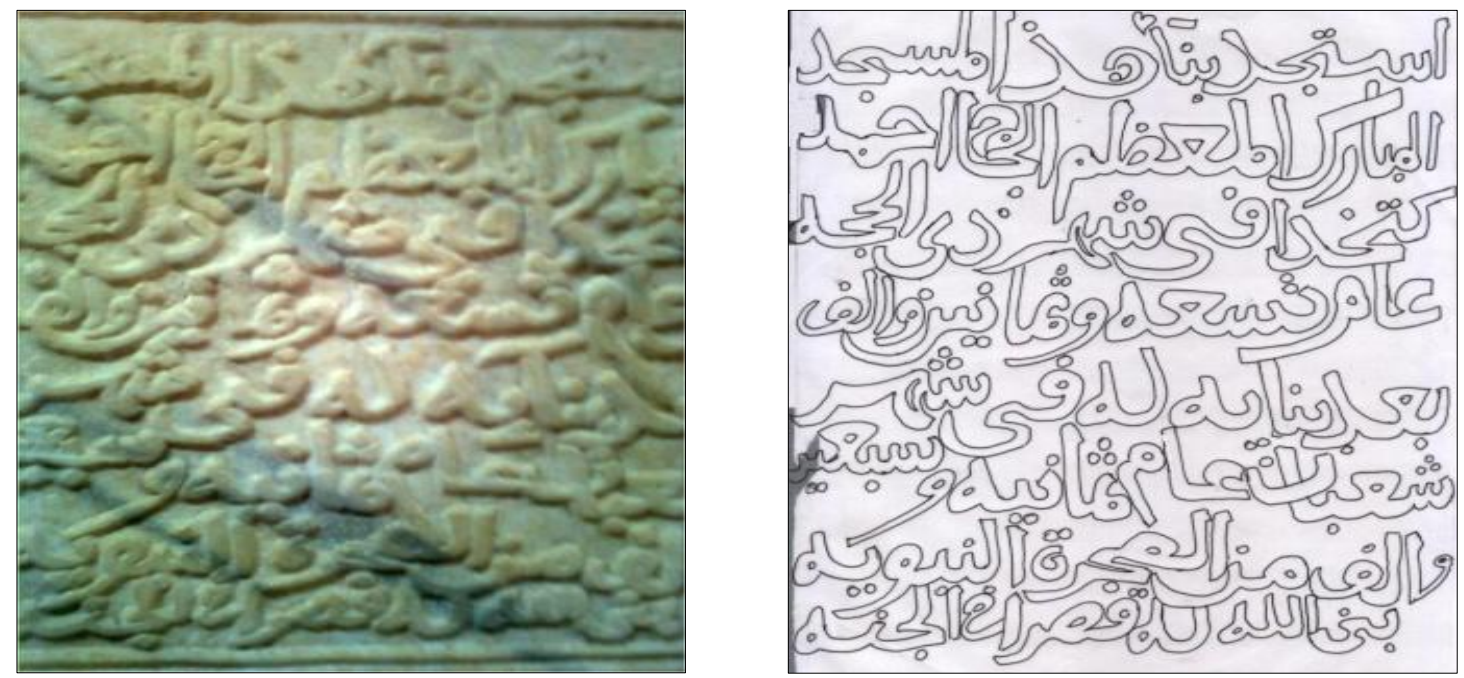

Plate \& Figure (2) renewal inscription of the red minaret mosque (1089 AH / 1768 AD)

\begin{tabular}{|c|c|}
\hline Inscription translation into English & Arabic inscription \\
\hline Haj Ahmad has restored the building & استجد بنا هذا المسجد \\
\hline of this holy and great mosque. & المبارك المعظم الحاج أحمد \\
\hline Katkhoda, in the month of Dhul Hijjah. & كتخدا فى شهر ذى الحجة \\
\hline In the year nine and eighty thousand. & من عام تسعة وثمانين و ألف \\
\hline After he built it in a month. & بعد بنايه لله فى شهر \\
\hline Sha'aban, in the year seventy-eight. & شعبان عام ثمانية وسبعين \\
\hline and a thousand of the Prophet's Hejra. & و ألف من الهجرة النبوية \\
\hline May Allah built him a palace in Paradise ${ }^{[B]}$. & بنى اله له قصر اً في الجنة \\
\hline
\end{tabular}

\subsubsection{The foundation Inscription of Yousuf Elmokney Mosque 1123 AH (1711} $A D)$ pl. \& fig. (3).

It's an inscription written in Arabic, consists of eight lines of poetry in Thuluth script coated with black color on white marble, the plate dimensions are 50

$\mathrm{cm} \times 60 \mathrm{~cm}$ and it has a break from the middle and clear restoration and erosion in some letters and words, the inscription is:
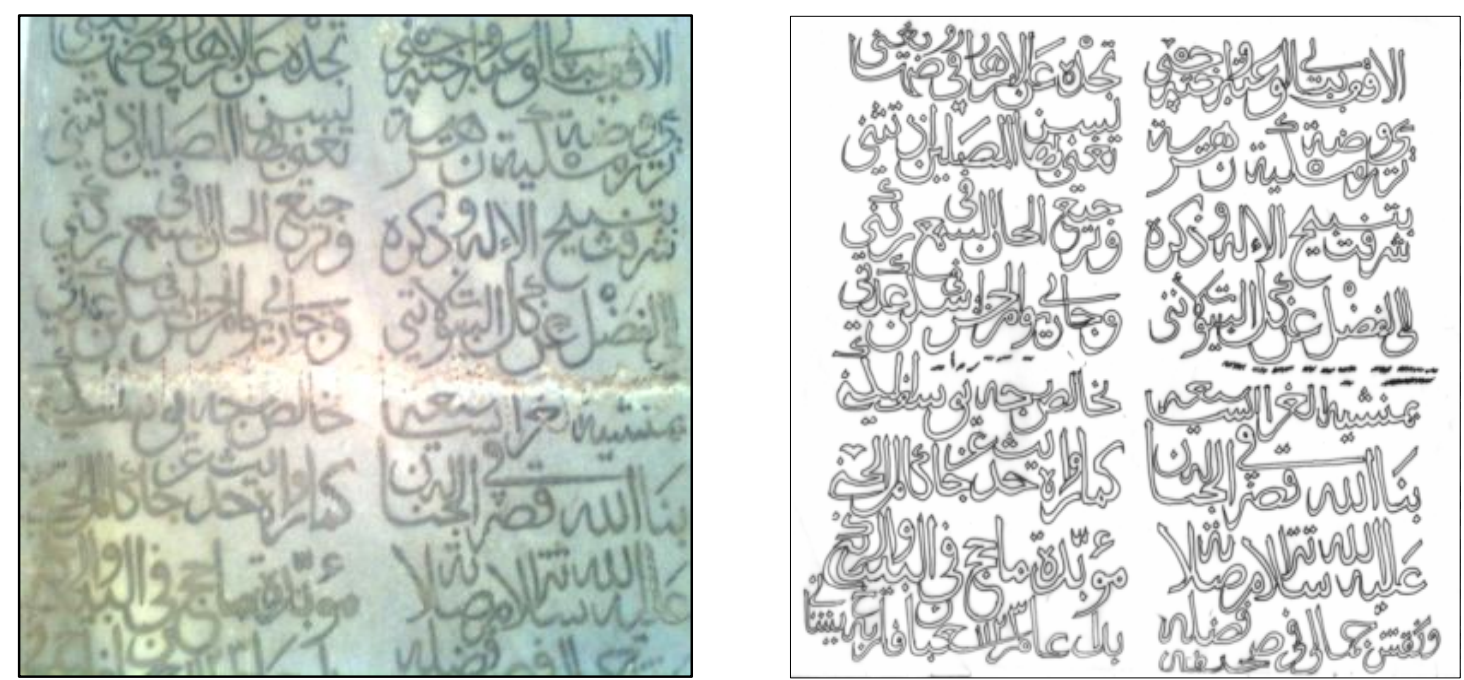

Plate \& Figure (3) foundation inscription of Yousuf Elmokney mosque 1123 AH\1711 AD 
Inscription translation into English

Stand on my door, consider it a garden and pick up, you will find it more satisfied than the flowers sing in its garden.

You will see kindergarten perfumed with musk and flourished, where prayers read "Yaseen"

Honored by the praise and mention to Allah and the echo of this praise in my corner.

I'll have the better thanks than any other houses because I' ll dwell in the day of judgment in (Adan), the paradise

In his honored construction, his effort, the sincere to Allah, Yousuf Elmokney

My Allah build a palace in Paradise for him as it's narrated by the prophet the completed beautiful.

the peace continued from Allah be upon him as the prayer continues and forever as the continued pilgrimage to Mecca.

His bounty is written in his paper, that appears full of goodness dated in sha'aban 1123, (Yasheny) ${ }^{[C]}$

\section{Arabic inscription}

$$
\text { ألا قف ببابي أو اعتبره جنة واجني }
$$

تجده عن الأزهار في روضها جنا يغنى

$$
\text { ترى روضة مسكيـــــة زهريـــــــة }
$$

يس تغنــى بهــا المصليــن إذ تنثى

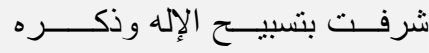

وترجيع ألحان السهــع في ركني

$$
\text { لي الفضــل عن كل البيوت لأنني }
$$

وجارى يوم الحشر اسكن في عدني

الخالَص لوجه الله يوسف المكنى

$$
\text { بنــــــا اله قصـــر ا في الجنــان له }
$$

كما رو اه حديث جا عن كامل الحسني له لهان

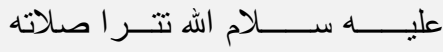

مؤبــــة ما حسج في البيت و الركني

ونقـش جمالي في صحيفة فضله

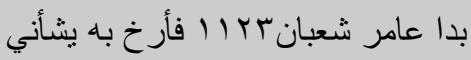

\subsubsection{The foundation Inscription of artillery building outside Tripoli $1268 \mathrm{AH} /$}

1851 AD, pl. \& fig. (4).

This inscription consists of two parts, the upper part contains Abdul Majeed Khan's Royal Tughra'a, and adjoined by flourished branch on a circular marble plate, its diameter is 60 $\mathrm{cm}$, it has a wooden frame with geometric decoration consists of half circles and the text of Tughra'a is "Abdul Majeed bin Mahmud bin Mustafa Khan". The lower part of the inscription is on a marble plate, its length $2.5 \mathrm{~m}$, and its width is $50 \mathrm{~cm}$, and its thickness is 18 $\mathrm{cm}$. In the middle, there is a rectangle divided by prominent borders to eight

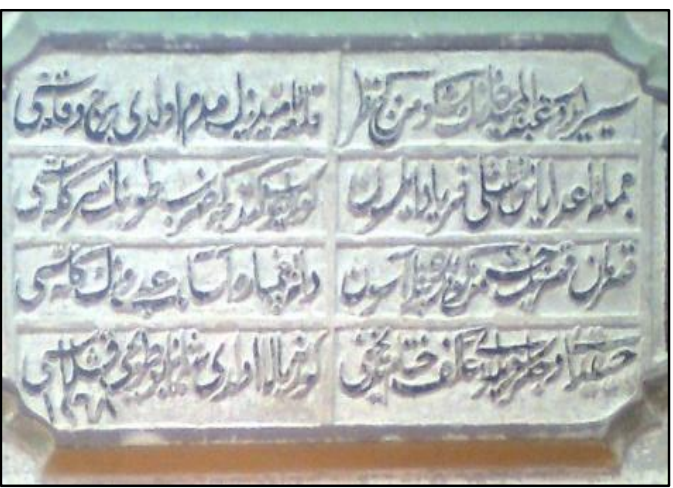

regions containing four verses of poetry in Turkish. It was written in prominent Alenstaliq script. The letters were painted black on a white background. It's surrounded from left and right by symmetric and balanced motifs consist of flag with red and black colors, and Lily flower, and blooming flower consists of ten petals. In the four corners of the frame, that surrounds the inscription, there is a quarter of a circle with arrowed decoration as symbol to the sun. The translation of the Turkish text is:

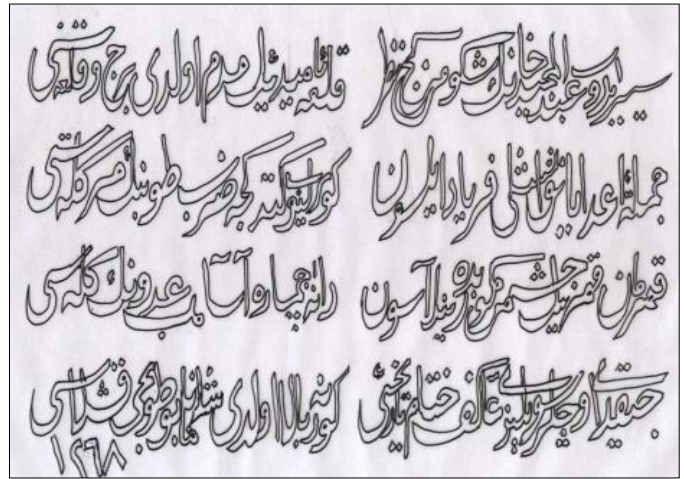

Plate \& Figure (4) foundation inscription of artillery building (1268 AH\1851AD) 
Translation into English

One of the commanders of the Sultan Abdul Majeed Khan, visited the tower and the Fort of Umeadi.

All the enemies cried of the fire burning, as they saw the artillery shell all the night.

The enemies saw the strength of this commander, who had flown the heads of his enemies using his cannons.

The enemies got out of the castle three by three, and Akef chronicled to this action, note the artillery battalion, that have become proud $^{[\mathrm{D}]}$.
Turkish inscription

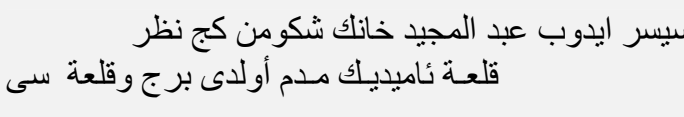

$$
\begin{aligned}
& \text { جملـة اعدا بانـق اتشلى فريـاد ايلسون }
\end{aligned}
$$

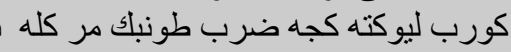$$
\text { قهرمان قهرينك جشم مكوبده رينك آسـون }
$$

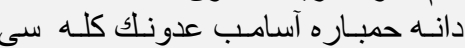

\subsection{The second section, analytical study of the inscriptions}

\subsubsection{The analytical study of the form of the inscriptions}

\subsubsection{Raw material}

The four inscriptions of our study were engraved on white marble, which was characterized by rigidity resulting from its natural composition, and therefore it was the longest livid decorative materials, and it was submissive and easily elaborated to the required size and luster to its surface [8]. Because these inscriptions were related to architectural foundations of princes and seniors of the state of Tripoli, who were keen to provide their works with establishment texts that carry their names along with their titles or honorary career and the dates of these foundations [9]. By noticing and examining the marble plates that carry the engraved inscriptionsthrough the field study-it was clear that they were not used before and it was new when the inscriptions were written. Due to the subordination of Tripoli to the Ottoman Empire in that period, it is likely that those pieces of marble were brought from Turkey itself, especially that most of the marble which commonly used in Ottoman architecture is characterized as being net transparent free from impurities [10]. With the spread of the Turkish Ottoman style in the States submitted to the Ottomans, including Tripoli, The use of marble was

\subsubsection{Methods of implementation of}

The implementation of three patterns of the four inscriptions under study were in relief carving, they are the spread in the settlements as a decorative material in the shape of marble plates, for a documentary purpose as we see in the establishment texts of most of the foundations [11]. Especially, when a group of Ottoman soldiers has entered the field of architecture, and they have the processing of building materials of marble, gypsum, and timber, this action necessitated the possession of the boats for the transport of these materials from their sources [12]. At the end the $12 \mathrm{AH} /$ $18 \mathrm{AD}$, the soldiers have reached to the degree of penetration in these crafts, so that they became an influential force [13]. Methods of forming, sculpting and polishing, were used to prepare the marble to write on. The manufacturer used the style of drawing holes, to give the desired shape according to the dimensions, and then draw the four faced design, and carve until their configuration became clear, and repeat this whenever the drawing has faded, and then refine the piece [14]. The sizes of the pieces of the marble used in the inscriptions indicate the accuracy used in the forming, carving, and polishing. Its area reflects its suitability to the inscriptions on it.

\section{of the inscriptions}

inscriptions of Bab Elbahr "the door of the sea", pl. (1), the renewal of the Red minaret mosque, pl. (2) and the Artillery 
building, pl. (4).Only one inscription was implemented by coating and inlaying style, it is the inscription of Yuosuf Elmokny mosque, pl. (3). In the style of relief carving, the ground itself is carved around the writings after selecting the outside, so that the writings will be highlighted after carving the ground and became above the floor level [15]. The documents called this process (Carving "naqr" on the marble) [16]. While the method of coating or inlaying was performed by using colored marble or a black past, which fills the carved ornaments or inscriptions [17]. This method is called in the documents (digging and burying) and it is performed by drawing the desired shape on marble and layering it half a centimeter or more deep and then fills it with colored marble on a cushion of gypsum [18]. The engraver and inlayer perform inscriptions and inlaying on the marble and sometimes one person may improve the two crafts [8]. The scribe may perform the engraving process by scribing the writings on the marble using chisels after determining the places of drawings and writings [19]. The engraver who works in carving or scribing writings needs to be acknowledged with the rules of the Arabic language and mastery of writing and performing the ornaments by digging and carving. He should be aware of

\subsubsection{Types of scripts used in the}

Two kinds of scripts were used in the inscriptions under study, in addition to "Tughra'a" drawing. The flexibility of Arabic calligraphy and the ease of its movement and its ability to be formed and ornamented, have enabled the Muslim calligrapher to form his letters according to the spaces prepared for writing [24].The Islamic unity in arts is clear in the art of Arabic calligraphy which was the result of technical exchange between Islamic peoples, where the manufacturers are moving from one place to another, the rulers were calling artists and craftsmen from all over the nations to build up their architecture and their artistic work [25] .The Ottoman compatibility between the texts, the space, the shapes and the ornaments surrounding [20]. In spite of the accuracy of the carving in the implementation of the four inscriptions of our study but none of the engravers or those who work on marble signed his name. The lack of manufacturers' signatures on their works is a general phenomenon in the Islamic Ages [21]. Workers of marble are a branch of the craftsmen and artisans in the Ottoman State, where they were called "sector of craftsmen (AL-CAR)" [22]. As the implementation of inscriptions varied, the forms of writing diversified as well, some of them have the form of horizontal lines, which is clear in the inscription of renewal of the Red minaret mosque, 1089 AH/1678 AD, fig.(2). Two of those inscriptions came in the form of lovely Ottoman Turkish poetry, One is the inscription of the restoration of $\mathrm{Bab} \mathrm{Al}$ Bahr tower 1022 $\mathrm{AH} / 1613 \mathrm{AD}$., fig (1), the other is the inscription of the establishment of Artillery Building 1268 AH/1851AD, fig (4). While the establishment inscription of Yuosuf Elmokney mosque 1123 AH/1711 AD was in Arabic poetry that belongs to the poetic-meter called "convergent" which weighs as follows: Faolon Faoloon Faolon Faolon..........Faolan Faolan Faolan Faolon [23].

\section{iptions}

Turkish was not against the artistic or cultural movements in these states. They also did not want their capital, Istanbul, to be the only city that has excelled people in various technical fields [26]. The ottoman artistic vision to calligraphy has been influenced by the legacy of Arabic calligraphy, which emphasizes the sanctity of the script and its artistic, objective, historical, documentary, and informational function [27]. The Ottoman authorities were practicing the policy of guardianship, encouragement and development of the script which has witnessed its largest artistic development [28]. The Ottoman Turkish left us a large number of inscriptions which have 
enriched our knowledge about the monuments relating to princes, people, and charity like the establishments of public utilities and its maintenance. It has also its artistic and religious importance [29]. The script has -for the products of Islamic art- a documentary role that gives archaeological, historical, and scientific value. The phrases written on the masterpiece may include many important historical facts that may shed light on various social aspects, and techniques [30]. The motive behind the Ottoman role in the development of Arabic calligraphy was not only documentary, but decorative as well. [27]. So, there shouldn't be astonishment of the harmony and consistency in writing between skilled artists who were members in the foundation of publishing Inscriptions "NASKI" great and important role in architectural ornamentation, and in enriching the decorative arts in general, even if we imagine that all these buildings and other works of art are completely free from writings, they will be poor and lack beauty [31]. The Ottoman influence on art in Tripoli, was distinguished from Egypt because of the ability of the Egyptian artist to integrate the incoming artistic elements with the local style and introducing it in a coherent manner [26].While in Tripoli, the Morocco script was the common script which was used before the advent of the Ottomans, and it was used only in the states of Ottoman Empire in North Africa [32]. One of the examples of the use of Kufic Moroccan script is the text of the renewal of "Annaqa mosque" in Tripoli 1019 AH/1610 by "Safr Dae" who re-built it in this period, as indicated by marble plaque installed on one of the doors of the main facade of the mosque [33], fig. (5). The oldest mosque in Tripoli was destroyed after the Spanish attack 916 AH/1510 AD [6]. For this reason, the Ottoman influence was clear in the use of some scripts that were not used in the inscriptions in Tripoli before the ottomans. some of these scripts are:

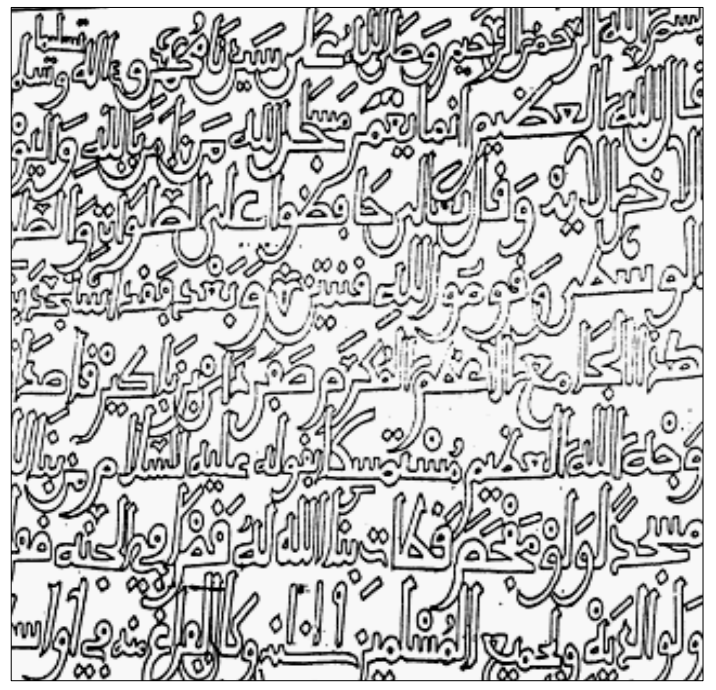

Figure (5) foundation inscription of Al-Naqah mosque, after, Elbahnasy S., 2004

Thuluth Script, it was used in three inscriptions out of the four - of our study- and they are: the inscription of; Bab Elbahr, pl. \& fig (1), and the Red Minaret mosque, pl. \& fig (2), and the mosque Yuosuf Elmokney mosque, pl. \& fig (3).The Thuluth script and many other flexible scripts are branches from Naskh which took the place of pride in the inscriptions of the ancient since the $6^{\text {th }}$ century $\mathrm{AH} / 12^{\text {th }} \mathrm{AD}$ [34]. It was differed why it was called Thuluth, was it because it is flexible and expanding, or because it is one-third of the roll area as the roll is 24 hair of a horse and the width of Thuluth is 8 hairs and they are a third of that [35]. Thuluth is considered the father or grandfather of all scripts that came 
after it, and all its types branched from it. It is also the most difficult script and the calligrapher will not be considered a master unless he mastered it [36]. The artistic structure of the Thuluth has stabilized after the $7^{\text {th }}$ century $\mathrm{AH} / 13^{\text {th }}$ $\mathrm{AD}$ and it began technically and functionally and gradually it took the place of Kufic scripts that began to erode both technically and functionally. Their presence was relatively limited to architecture. According to historical sources- among them Ottoman- the Ottoman school had taken a Thuluth from the Egyptian school [27]. Great ottoman calligraphers have developed and improved the Ottoman script [37]. Thuluth script became popular in the Ottoman Empire as a decorative script; especially between the scripts of archaeological inscriptions [38].The Ottoman school gave the features to the Thuluth script which makes it really a classic pattern. Thanks to their efforts it turns into a type of anatomical analysis through the application of its letters and forms [31]. Some Ottoman Sultans have practiced calligraphy, the best one of them was Sultan Mahmud II (1223-1255 AH/1808 1839 AD), the father of Sultan "Abdul Majeed" [39]. Thuluth jalil script has started in the $9^{\text {th }}$ century AH/15 AD by calligraphers who preceded its first official inventor Ahmad Qara Hsary according to the Ottoman resources [40]. The Thuluth Jail script requires the knowledge of perspective and justifying the sizes of letters and its positions and the accuracy of its implementation to achieve the dual function, the documentary and aesthetic [37].Comparing with Cairo in the Ottoman period, we find that although Thuluth script was playing a prominent role in decorating most of Cairo architecture, but one of the researchers mentioned that he Thuluth didn't develop in the comprehensive sense of the word in the Ottoman period [41]. But late inscriptions, of the second half of the $12^{\text {th }}$.C.AH $/ 18^{\text {th }}$.C.AD that reached to uswere at the highest degree of quality and proficiency, and most of them were perfect in shape and content [26], the characteristic of the Thuluth script on the inscriptions under study could be explained as follow: (a) Flexibility and Softness, It is what the writers expressed as "It is nearer to oil more than expanding" [35].So, we find that its letters have a flexible angles opposite to Naskh that has sharp angles, and this is clear with the letter in the inscription of Yuosuf Elmokney mosque, fig. (3). (b) Overlap between letters and words, this depends on the ability of the calligrapher [42], There is a light and heavy overlap in different structures [43], examples of words in the inscriptions: (luta ser nathar) in the "Bab Al Bahr Tower" inscription, and (Tara rawdatan), and (hadeeth ga'a) in the inscription of Yuosuf Elmokney mosque. (c) Words start and end in a thin shape, and this gives it a kind of beauty and these thin letters can be only shaped with the tip of the pen [35]. Therefore these letters need to be diagonally chamfered which will assist the calligrapher to achieve the thickness of the letters as we can see in the final "ra'a, Noon, and Wao" and the final "Ha'a and Ra'a", in the inscription of Yuosuf Elmokney mosque. (d) Tarwees, is required in a Thuluth script, this means that the beginnings of the letters bend its tip to the bottom, and this can be applied to the individual Alf and the jeem and its two sisters, and Tae and the connected Caf and individual Lam and the beginning tip [44], the examples of these are found in the inscriptions of $\mathrm{Bab}$ Elbahr, and the Red Minaret mosque, Yuosuf Elmokney mosque, fig. (6-a, b). (e) Most of its letters, should be empty from inside, such as, Sad and its sister, Ayen and its sister Fa'a, Qaf, Meem, Ha'a, and Wao [35]. These letters should be open and empty from inside, and this can be seen in the inscriptions of "Bab Al Bahr Tower", the Red Minaret mosque and Yuosuf Elmokney mosque. (f) A lot of vowel points, this wasn't found in other scripts, and it's clear in the words of Bab Elbahr inscription, and it is less in the other two inscriptions 

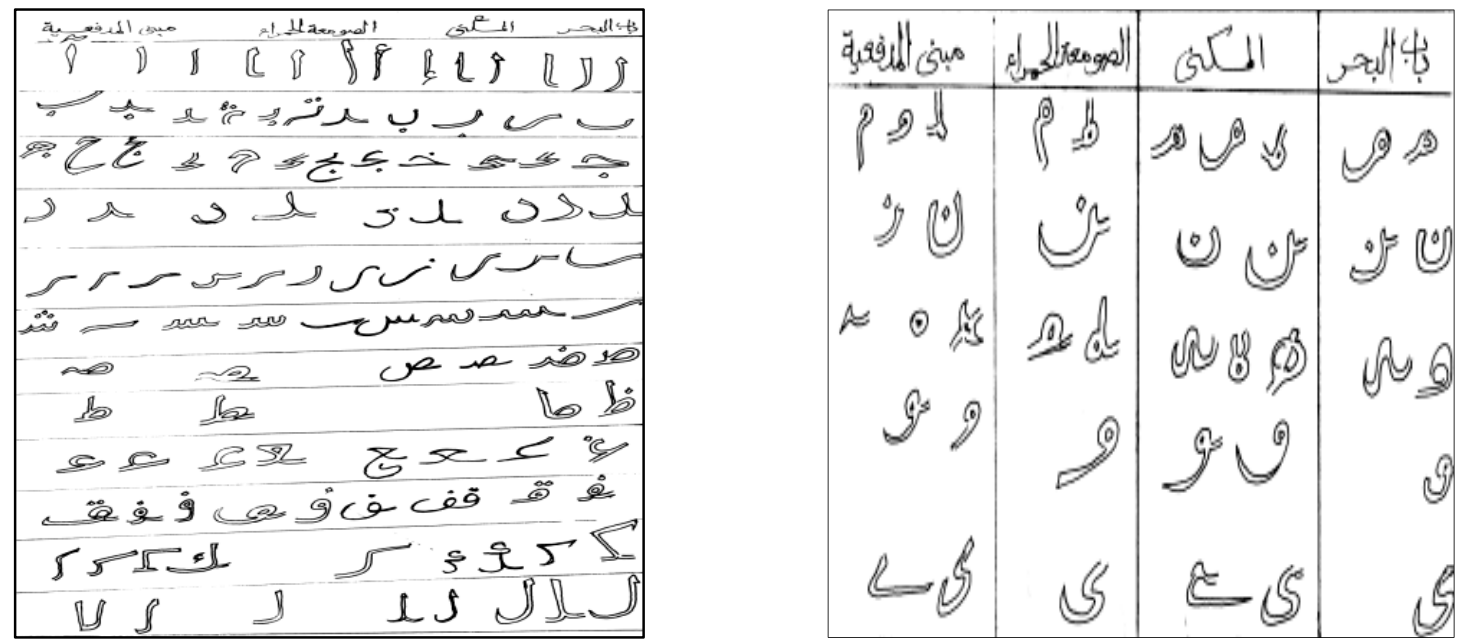

Figure (6) $\underline{\mathbf{a}}$ analyses to letters in the inscriptions from $A-L($ Alef $-L a m) \underline{\mathbf{b}}$ analyses to letters in the inscriptions from $\mathrm{M}-\mathrm{Y}$

Alnastaliq Script, it was used in the the inscription of the establishment of artillery building outside Tripoli 1268 AH/1851 AD, pl. \& fig. (4). Alnastaliq script was invented by the Persians in the $9^{\text {th }}$ century. $\mathrm{AH}-15^{\text {th }} \mathrm{AD}$, and it was derived from Arabic Naskh script that was known since the $6^{\text {th }}$ century $\mathrm{AH}-12^{\text {th }}$ $\mathrm{AD}$ and Persian Ta'aliq script, that was known since the $7^{\text {th }}$ century $\mathrm{AH} / 13^{\text {th }}$ AD [25]. It is likely that Mir Ali Tabrizi, the calligrapher is the person who invented it and put its rules. He works in Taimurlank's court, and he was also one of the most famous calligraphers in Herat and Bukhara in the $9^{\text {th }}$ century $\mathrm{AH} / 15^{\text {th }}$ $\mathrm{AD}$ [45]. The Ottomans inherited Alnastaliq script from the Persians and knew it as "Ta'aliq". It is mentioned that the era of Sultan Mohammed the Conqueror"833-866AH" was the beginning of the use of this functional script to the Ottoman state [46]. It's also said that" Shah Qasim Tabrizi" brought in the $10^{\text {th }}$ century $\mathrm{AH} / 16^{\text {th }} \mathrm{AD}$., this style of writing to Istanbul [47]. But in the educational level the most prominent calligraphers who brought it was Darwish Abdi El Bukhari who died in 1057 $\mathrm{AH} / 1647 \mathrm{AD}$, was the student of Alhasani. Many calligraphers have followed and perfected his style; one of

Tughra'a drawing, it came above the establishment inscription of Artillery building outside Tripoli, pl. (5) \& fig.(8). It belongs to Sultan Abdul Majeed, the

them is the great Ottoman Ta'aliq calligrapher, Muhammad Asad Yasari who died in $1213 \mathrm{AH} / 1798 \mathrm{AD}$ ), who invented specific forms which became the basis of the new Ottoman way which helped the emergence of Ta'aliq Jali [27][31]. In any case, Ta'aliq became a chosen script in writing on the buildings since the $12^{\text {th }}$ century $\mathrm{AH} / 18^{\text {th }} \mathrm{AD}$ [31].The Turkish Ottoman dealt with the calligraphy 'paying in attention its functional and cultural role, as well as the possibility to develop and distinguish it [27]. The most important features that distinguish Alenstaliq in the inscriptions of Artillery building are: - It combines the features of Naskh and Ta'aliq as understood from its name and it's simpler, softer, shorter and more flexible than the Naskh and Taliq. [44]. - Its letters can't be mixed with any other letters and sometimes seen has three points from the bottom for the ornamental purpose, the individual Ha'a takes a round shape, fig (4). - It's free from vowel points and ornamentation because the size and the shape of letters can be a beauty in itself [43]. - The extensions are downward, the upright letters aren't long, and the ratio of the thickness of pen to its width is 1: 3 in Turkish writing, fig (7).

son of Mahmud Khan. Tughra'a, the signature of the Sultan, was a Turkish tradition that the Seljuks and Mamluk sultans of Egypt knew and lasted during 
the Ottoman period. It was entrusted to the most brilliant and clever artist to write tughra'a and he was called "Tughrae" The employee who is responsible for this relationship is called "Nashanjy". He prepared Tughra'a by himself or entrusted it to Tughrae. Tughra'a is including the name of the Sultan and his fathers, and his various titles, such as Shah, and Khan [27][31]. Despite that some people consider Tughra'a a kind of ottoman arbitrary script types, but others considered it closed artistic and functional installation for signatures of Ottoman sultans and it's mainly derived from the compound Thuluth script [27]. We tend to take this view, where the Ottoman sultans ask the greatest contemporary calligraphers to design a private tughra'a for them. Sultan Mahmud the second, has done this, when he asked the famous calligrapher Mustafa Rakem [39]. The Turkish tended to use the interconnected and joined scripts, so they liked much the compound Thuluth, and this is what led to the existence of "tughra'a", $\mathrm{pl}_{\mathrm{s} .}(6,7,8)$. It can be said that the Ottomans were able to convey the Arabic letters from being symbols to a graphic material, where the artistic environment became awareness of the aesthetic role that became a purpose in itself [48], fig. (8). Adapting and drawing of tughra'a has led to the disposition of the familiar rules of the script and going out of the process of writing to drawing. But at the same time, tughra'a was written beautifully in Thuluth script in a special form [49]. And the presence of the royal tughra'a of Abdul Majeed Bin Mahmud Khan above the establishment inscription of Atillery building in Tripoli refers to that Sultan has given the order of the construction by himself and one of his generals has performed.

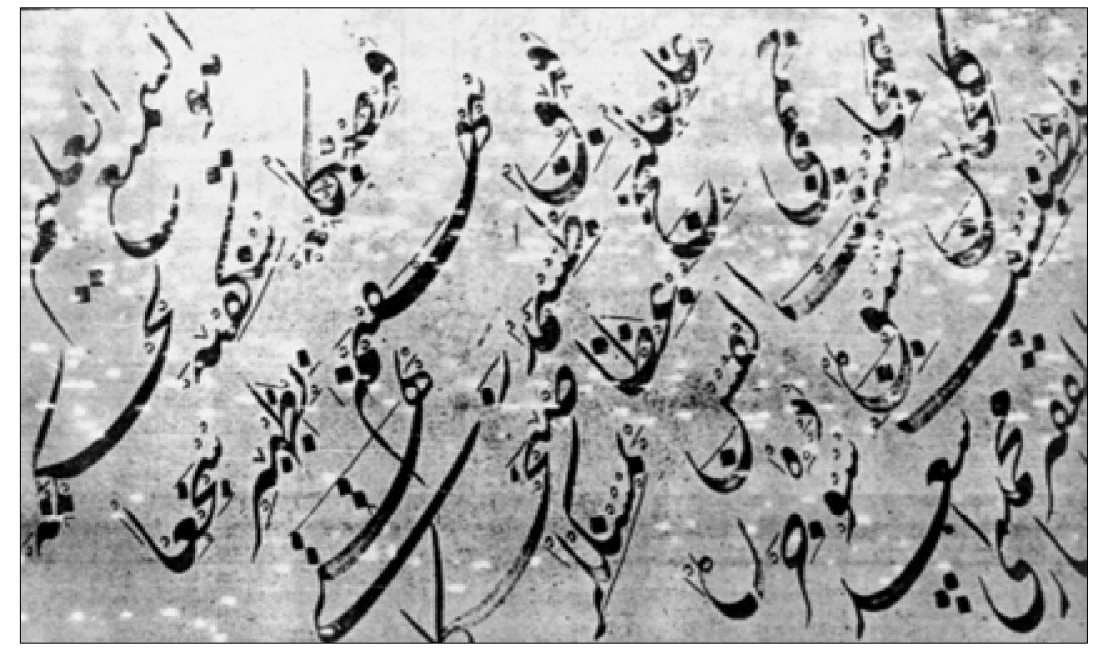

Figure (7) attribution of letters of Turkish Nastaeliq

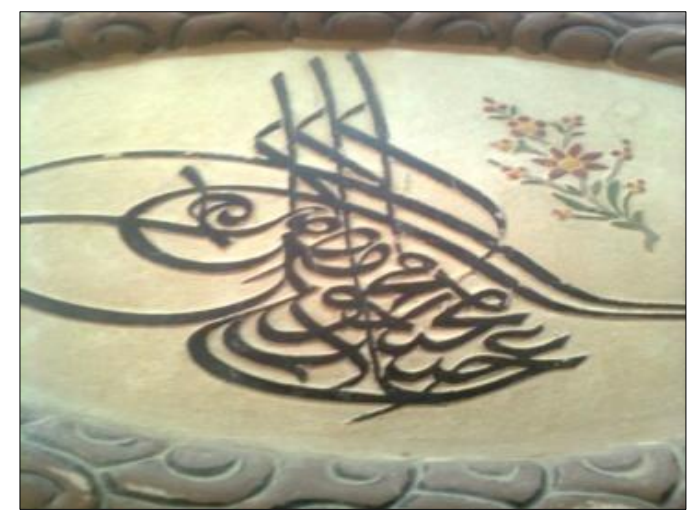

Plate (5) Tughra'a of Sultan Abdul Majeed khan above the inscription of artillery building

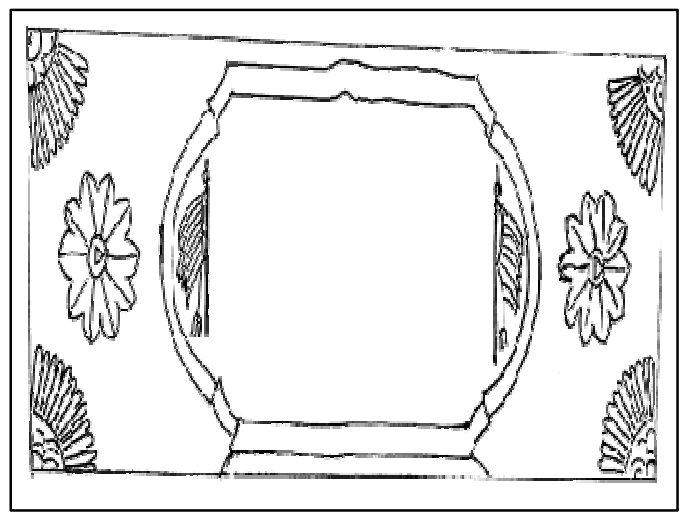

Figure (8) decoration around inscription of artillery building 


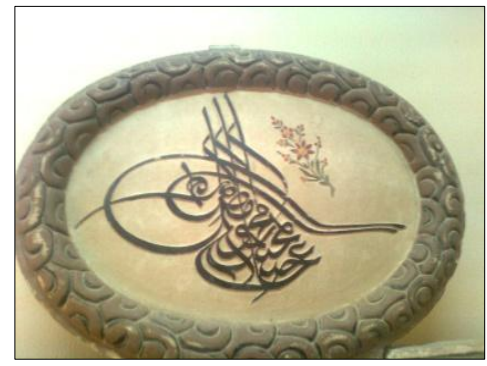

Plate (6) details Tughra'a of Sultan Abdul Majeed khan

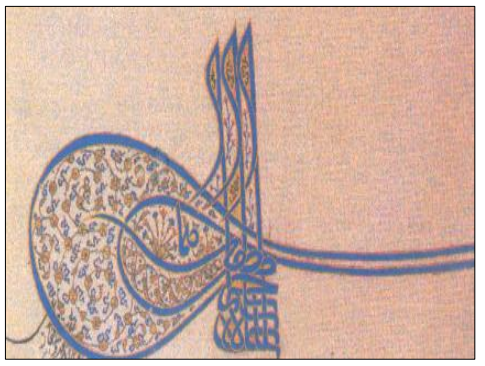

Plate (7) Tughra'a of Sultan Suleiman the Magnificent, after Aslan'aba

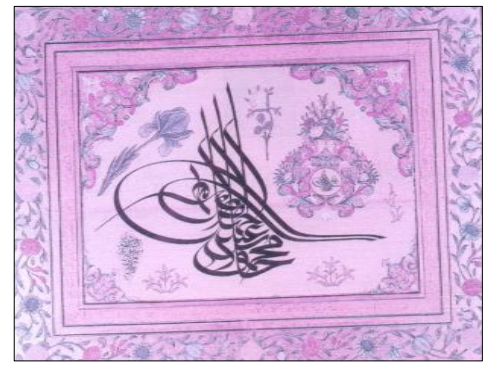

Plate (8) Tughra'a of Sultan Mahmud The second, after, Earthly beauty

\subsubsection{Decoration associated with the inscriptions}

The floral decorations came on two inscriptions of Bab lbahr, fig. (1) and the Artillery building, fig. (9), both connected with a defense foundation. It is known that the Muslim artist has produced a lot of plant elements in modified forms with unique, Islamic, Arabic, features [50]. The Turkish Ottoman has used the decorative elements from nature [51]. Turkish has taken from the flowers and plants of their country the elements of their new Turkish style. The Ottoman artist has developed arabesque decoration, so we can call the Romi decoration, Ottoman arabesque [52], fig. (10) as we see on the "Bab Al Bahr Tower" inscription. The Ottoman artist chose Lily flower, fig. (11) and pomegranates fruit, and the spear shape leaves which was called the dental leave [53]. The origin of Romi decoration was found in the third and fourth Samara model, and the Seljuks have developed this type of decoration by adding new elements [54]. The decorative elements have been modified to the extend that it became away from its origin, so Romi is the term launched by the Turkish to the decorative style, which consists of modified plant and animal elements [51]. The branches and leaves of this decoration were drawn by the manner that doesn't follow the shape or directions of the natural one, so we can call it Ottoman floral decoration, they devolved it in a wonderful way, so it has a great impact on its viewer [25]. The second plant element is found in the foundation inscription of Artillery building. It's the blooming flower with ten petals, pl. (9) \& fig. (12), and it's one of the two forms that the flowers are carried out on the applied arts, in this way, the leaves or petals are coordinated in the vicinity of ring around the center of the flower, and it can be said that the flower has a simple appearance, it has acquired its simplicity from the leaves [55]. Although there are examples of this flower since the $2^{\text {nd }}$ century $\mathrm{AH} / 8^{\text {th }} \mathrm{AD}$ from Syria, fig. (13), and it continued to be used in Iran at the age of Seljuk, where it was consisted of a middle circle surrounded by smaller circles which reflect a lot of blooming flowers [56]. But it's characterized in the Artillery building inscription by a triangle in the middle circle from which the petals come out and every petal has two veins connecting the end of the petal, pl. (9) \& fig. (12). The third plant element is Lily flower at the left and right of Artillery building inscription, fig (11). The Ottomans used this flower a lot in their decorative subjects in the $12^{\text {th }}$ century. $\mathrm{AH} / 18^{\text {th }} \mathrm{AD}$, especially in the age of Ahmed the third, (1115-1143 AH/17031730AD), whose age was known as the age of Lily flower [51]. Not only did the Ottomans pay attention to this decoration for its beauty, but it was connected with ideology concepts as well. It's noticeable that the letters of this flower is the same letters of Allah, and the same letters of the word "moon" (helal) [25][57]. At that time, the moon was a symbol to Ottoman 
state so, their artists drew it in shapes resemble their symbol that distinguishes their state, fig. (14) .The artist in this inscription which we study could fill the

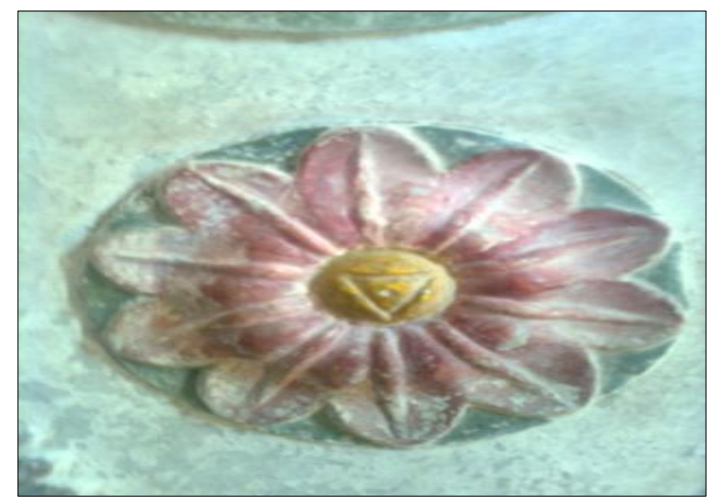

Plate (9) open flowers around the inscription of artillery building

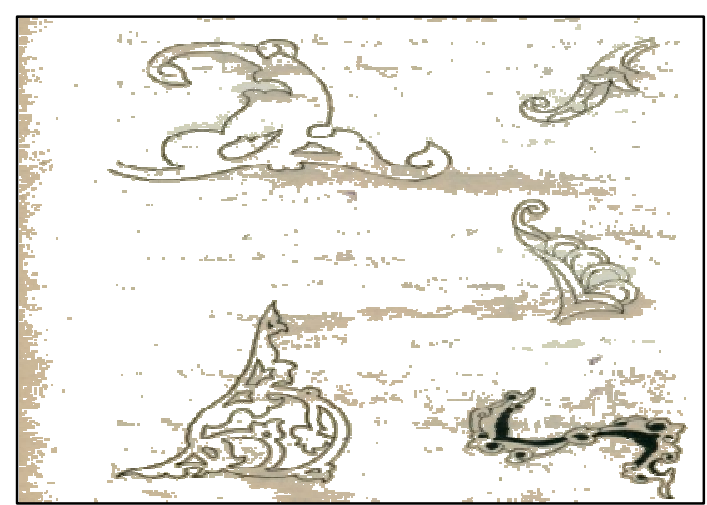

Figure (10) Romi decoration, after Maher, S. around spaces depending on rhythm, balance, and repetition of the position of the sun, the two flags, and the right and left flowers, fig. (9).

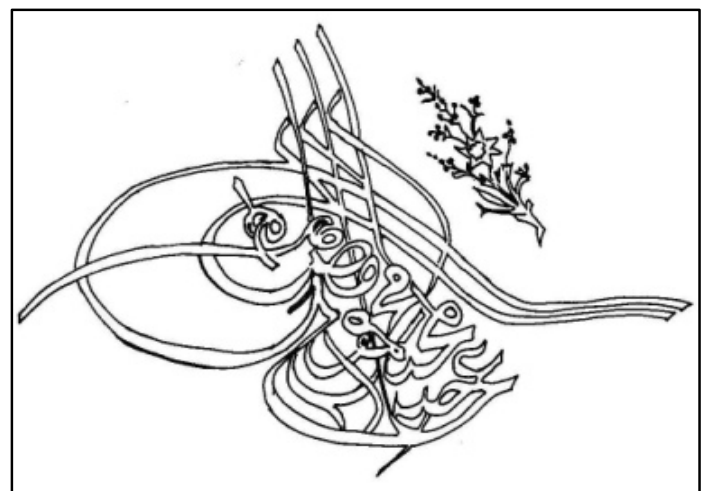

Figure (9) Tughra'a of Sultan Abdul Majeed khan above the inscription of artillery building

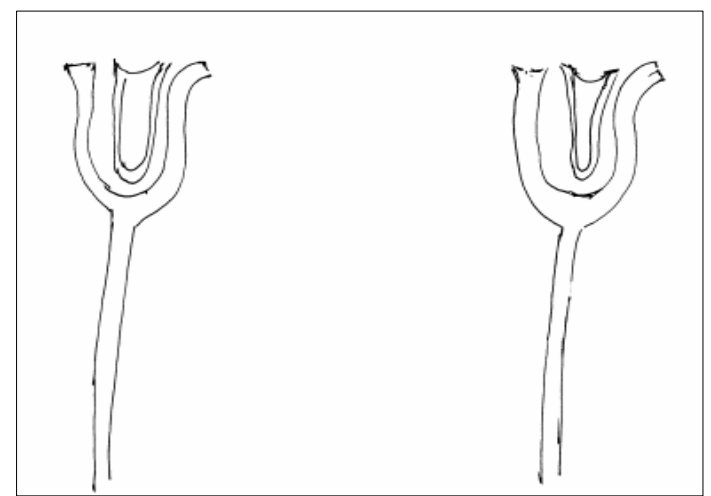

Figure (11) Lily flowers around the inscription of artillery building

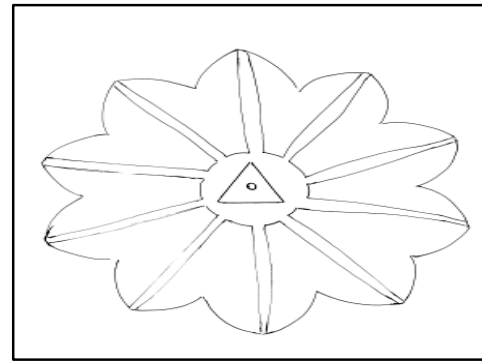

Figure (12) open flower around the inscription of artillery building

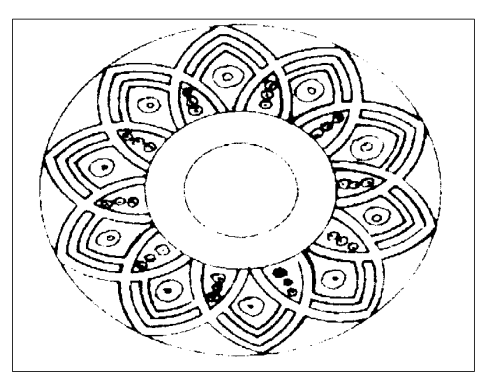

Figure (13) open flower on Assyrian panel, after Yasin, A.

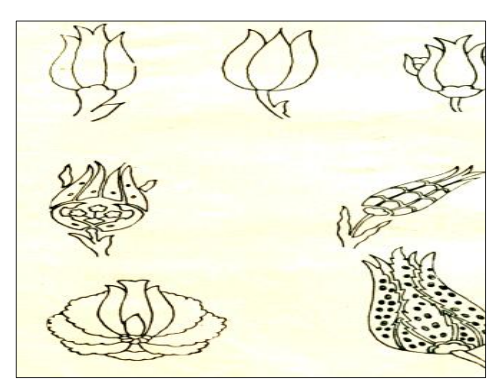

Figure (14) lily flowers in ottoman art, after Maher, S.

\subsubsection{Language}

Two inscriptions -in this studywere written in Arabic, which are the Red Minaret inscription, pl. \& fig. (2) and the inscription of Yousuf Elmokney mosque, pl. \& fig. (3). Two inscriptions were written in Ottoman Turkish, they are Bab Elbahr inscription, pl. \& fig. (1) and the inscription of the establishment of artillery building, pl. \& fig. (4). While the

Arabs failed to eliminate the Turkish language in Turkey, which were condemned to them, they made them write their national language in Arabic letters [58]. The cultural interference required linguistic overlap between Arabic, Turkish and Persian language to create words of three languages taking the same meaning in the three languages [59]. 
The Turkish language used in the inscriptions has been influenced by the Arabic language, where we see inscription which has taken the form of lovely poetry, had required a delay or advance of some Ottoman words ${ }^{[\mathrm{E}]}$, in addition to that, it contains some Arabic words. Spiritual bond played a great role in calligraphy in Islamic countries that have different cultures, which led to artistic unity between Islamic countries [60]. We noticed the primacy of the use of Turkish language in the inscriptions of Tripoli by about three decades before its use in Cairo .This was represented in $\mathrm{Bab} \mathrm{Al} \mathrm{Bahr}$ inscription 1022 AH/1613 AD, pl. \& fig. (1). The oldest use of Turkish in the 1.2.2. The analytical study of the form of the inscriptions in terms of content

\subsubsection{Names, titles and jobs}

Inscriptions, of our study-had several names, jobs and titles which are important for the content of these inscriptions. Names who are mentioned had a link with the jobs of architecture on one hand, and the Ottoman administration of the State of Tripoli, on the other, and through them we can devise some important Ottoman influences on this state (Tripoli), and they are (a) Titles and jobs in Bab Elbahr inscription, Safr Dey is the person to whom the renewal of Bab Elbahr is related $1022 \mathrm{AH} / 1613 \mathrm{AD}$. And he is the first who was dubbed the title "Dey" among the Ottoman rulers of Tripoli. He wasn't appointed by the Ottoman Sultan as it was followed, but he was appointed by "Protecting Janissary "in Tripoli, so he had this title "Dey" [45]. He also rebuilt the mosque of "Al Naqah" in Tripoli 1019 AH/1610 AD, and this was after the Spanish had destroyed it 916 AH/1510 $\mathrm{AD}$, after the Fatimid's renewal before. The foundation inscription of the mosque refers to this renewal [6].In this inscription, he was entitled "The Prince of Lowa'a" and the prince in the language is the person with the command and domination, and it's one of the job titles that were also used as honorary titles [62]. The "Prince of Lowa'a" means a commander of a military division, and inscriptions of Cairo returns to the postmid- of, $11^{\text {th }}$ century AH/17 ${ }^{\text {th }} \mathrm{AD}$ [54]. In general, the Turkish inscriptions in Tripoli mosques are few, as it's in Cairo in the same period. The use of Arabic script in writing in the Turkish Ottoman language had been maintained in the official education until the early era of Turkish regulation $1255 \mathrm{AH} / 1839 \mathrm{AD}$, but since this date, it turns to the role of Turkification [61]. But this did not happen to the inscriptions in the states outside Ottoman Turkey as we can see in the foundation inscription of the Artillery building in Tripoli 1268 AH/1851 AD, carved in Turkish language but in Arabic letters. was one of the highest ranks in the Ottoman period [12]. It also means that the person entitled with it has a "Royal Brigade "the right to raise the Royal banner in his motorcade as the evidence of high position [63]. He may obtain this title after becoming the governor of Tripoli. The State was divided into smaller administrative divisions known as "Sanjaqs", its governor was nicknamed the prince of the banner. The number of "Sanjaqs" in the Ottoman Empire was about 290 "Sanjaqs", governed by the "beys" a banner is held by them [64]. His glory: It was nicknamed to " Safr Dae "in the inscription, the friend (sahib) in the language which refers to the partner (friend) and it's a title of the civilian Minister [35], and it was continued in the age of the Ayyubids, Mamluks, and it was located in a series of titles, before the title of the definition because it's one of the titles referring to the job [62]. Muzaffar: From "Zafar" which is a victory, the title includes a religious meaning in addition to a military meaning, because it means that the person who bears this title is supported from Allah who will enable him to overcome his enemies, this title was known in the Islamic world since the $4^{\text {th }}$ century $\mathrm{AH} / 10^{\text {th }} \mathrm{AD}[62]$. (b) Titles and jobs in the red minaret mosque 
inscription, this mosque was built by Ahmed Katkhoda and he renewed it after that, and his titles in the inscription are; Haj: It is called to the person who performed pilgrimage to the Holy Mosque in Mecca and the performance of this duty is a matter of praise [62]. It's one of the noblest titles obtained by the Muslim in the Ottoman period, and a lot of Egypt's pashas in this period were entitled with this title . [65]. Katkhoda: In Turkish and in Persian language "Katkhoda" means the master of the house and its owner, and it's used by the Persians to refer to the distinguished man and the king, and in Turkey, it means the employee in charge, the agent and the Secretary [66]. The ruler of Ottoman territories has agents known as katkhoda. Firmans were sent from Sultan to the Royal governors of Ottoman by this Katkhoda [67]. (c) The titles in the inscription of Yousuf Elmokney mosque, Elmokney was originally a family from Safakus of Tunisia, one of which was Abu Abdullah, Elmokney, who was a famous scholar and scientist [68]. It was mentioned that one of the members of this family, was the governor of Safakus [69]. Elmokney family was famous in the cultural and intellectual society in Tripoli in the $11^{\text {th }}$ century $\mathrm{AH} / 17^{\text {th }}$ AD [3]. The titles and epithets that mentioned in this inscription are Complete beautiful: Complete (kamel) is a title of ministers since the time of the Fatimid Al-Mustansir and it's noticeable that it was given to the ministers because of the highness of its meaning [3]. The Complete was a special adjective to King Mohammed bin Aladel Abu Bakr, the fifth king of the Ayyubid dynasty in Egypt [70]. The "complete beautiful" (kamel elhusney) is ended with the final (Ya'a) to go with the poetic rhyme, this adjective qualified the Prophet and shouldn't be used for any person. (d) The titles and jobs of the foundation inscription of Artillery building, its construction is attributed to Sultan Abdul Majeed bin Mahmud the second (12551277 AH/1839-1861 AD). This Sultan is the one who transferred the government to the palace "Dilma Bghshah" that was built during his reign. The Ottoman sultans ruled from Tobkabo palace, which was attributed to Sultan Mohammed the conqueror [25]. It was mentioned that Sultan Abdul-Majeed was generous with calligraphers and he himself was a calligrapher graduated on the hand of Mustafa Izzat 1259 AH / 1843 AD. His father Sultan Mahmud was a disciple of calligrapher Mustafa Rakem and he asked him to put a Private Tughra'a for him [39], pl (8). Sultan Abdul-Majeed has dubbed in the inscription the title of Khan. Khan is a Turkish title that's given to the older princes in the Turkish tribes since the first or second century of Hejra, it means the President. This title was launched to the governors of the Mongols, and then went to some parts of the Muslim world with the Turkish and the Mongols as a symbol of the Sultanate [62]. In the Ottoman period, it became a title of the sultans, as it was considered one of the titles of respect to the king sultans [70]. There was a religious link that connected the national Muslims of the State with the Ottoman Sultan, as he has the ruling dominant authority, so it seemed so obvious that the Arab provinces, which was loyal to the Ottoman state were looking at it as a protective shield that protects them from the evils and the ambitions of European colonialism [4]. Leader (Commander): it is given to one of the Sultan Abdul-Majeed Leaders who was responsible for the establishment of Artillery building which was dated in this inscription .A leader is the name of the job launched to the person who leads the army and also it's used as an emeritus title since the time of Al-Aziz, the Fatimid [62]. Akef: He is Akef Pasha, who may have organized the poetic foundation text of the artillery building. He was born in the city of (de Gazat) and came to Istanbul and worked in the era before $1839 \mathrm{AD}$ in the Turkish Ministry of foreign affair, then a leader of the city "Qoja Ali", then isolated and exiled to 
Edirne .After that he was permitted to stay in Istanbul after regulating his writing, that's dating to the birth of Prince Abdul Majeed. Akef pasha has regulated

\subsubsection{The foundations that the inscriptions dating}

$\mathbf{1}^{\text {st }}$ inscription, dating to the restoration of Bab Elbahr in the walls of Tripoli, fig (15) in 1022 AH/1613 AD. The oldest walls of Tripoli were founded by the Phoenicians or the Carthaginians in the early fifth century BC, probably it was originally called "uaiat" and "Eya" in Phoenician times, then "Oya" and Tripolis in Roman times, and it was the name given to the three cities (Oya Libtis, and Sabratha).After the weakness of Libtis and Sabratha, Oya was called Tripoli instead of Tripolis [6]. After the authority moved to the Byzantines, a new historical period began to the walls and doors of the city of Tripoli. When alBakri, the historian visited the city, after the reign of Aghlabids in (184-296 AH / 800-909 AD), in the $4^{\text {th }}$ century $\mathrm{AH} / 10^{\text {th }}$ $\mathrm{AD}$, he described the city saying "Tripoli is surrounded by a huge wall great in its architecture" [72] [45]. At the beginning of the $8^{\text {th }}$ century $\mathrm{AH} / 14^{\text {th }} \mathrm{AD}$, when the traveler" Tajani" visited it, he stated that he saw a great carefulness and a great architecture in its walls, and this is what he didn't see in any other city, through his description, it's understood that its wall was peppered with a set of doors, among them is Bab Elbahr [45]. Tripoli citadel was famous since the end of $9^{\text {th }}$ century $\mathrm{AH} / 15^{\text {th }} \mathrm{AD}$, and its fences were irregular fivefold and this happened since the $10^{\text {th }}$ century $\mathrm{AH} / 16^{\text {th }}$ AD. The Ottomans have introduced some changes to the features of the old city, but the changes did not affect substantially on the Arab-Islamic features, because of the similarity of concepts in the planning of Ottoman cities to a large extent with those throughout the Islamic Maghreb countries [6]. Bab Elbahr lies in the northeast corner of the city facing the sea, pl. (10) \& fig. (15). The inscription stated that Safr Dae is the person who renovated it because of its defensive importance. The current way of construction of the the first models of his prose and "The collection of Akif Pasha Poetry" was from his literary works [71].

tower with its square base, reflects the method of military construction followed in the Maghreb countries since "AlMowahdeen state", which was based on the use of cob, a type of clay mixed with gravel, sand and lime that was put between wooden panels, so that it became solid as stone. As cob replaced the stone in building also, the polygonal towers replaced the round ones. The cause behind the interest of Tripoli Ottoman governors to repair the city walls and doors was the Ottoman caution of any European aggression that may fall on Tripoli by the Spanish or another like Malta jockeys. This may explain the interest of the Ottoman authorities that was directed mostly towards the military fields more than the civilian aspects of Tripoli. $2^{\text {nd }}$ inscription, it is dating to the renewal of the red minaret mosque by Ahmed Katkhoda. This inscription is important because It's only in our case study which give the first date of the establishment of the foundation (1079 $\mathrm{AH} / 1668 \mathrm{AD})$, and the renewal date $(1089$ AH/1678 AD) for the same originator of the building. This mosque is located outside the walls of the old city. It's considered one of the small mosques, which most of them return to the Ottoman existence in Libya. The renewal of these mosques has given them the distinctive features of the architecture in those periods. "Messana" has said, despite the length of the Turkish era in Libyan country, including Tripoli, yet there is no architectural school, but we see an imitation to the Anatolian design, which shares with its Libyan equivalent in some aspects [6]. The Libyan architecture in the period of Ottoman existence was able to combine the local Moroccan style and the expatriate Ottoman style despite its influence of the newcomer Ottoman architectural style in its planning or 
architectural and decorative elements. $\mathbf{3}^{\text {rd }}$ inscription, it's the inscription that dating to the establishment of Yuosuf Elmokney mosque $1123 \mathrm{AH} / 1711 \mathrm{AD}$, which lies in "Mansheya" in Tripoli. The sanctuary is a square, its side length is $6.5 \mathrm{~m}$, and roofed with a dome based on squinches. [3]. The inscription in the terms of content refers to several statements of publicity describe this mosque with several descriptions such as: "a favor of all the houses is for me" The prayer refers to the founder saying as "My Allah builds him a palace in Paradise", in reference to the Hadith "Whoever builds a mosque to Allah, Allah will build him a house in Paradise like it" [73]. Despite the Moroccan origin of the founder of the mosque- because he is from Tunisia- yet the method of implementation, the type of the script, and the method of dating, all confirm the Ottoman influence in addition to the method of planning and

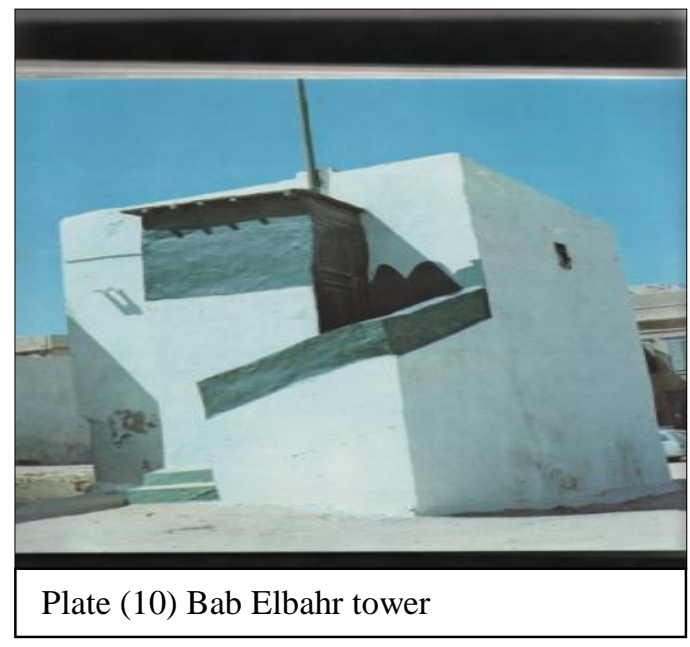

\subsubsection{The method of dating}

In the current study, dating style differs from one inscription to another, dating was in numbers in the Tower of $\mathrm{Bab} \mathrm{Al}$ Bahr inscription and in letters in inscription of the Red Minaret mosque while it was by letters calculation in the establishment of Yousuf Elmokney mosque and Artillery building. In the early Hijra centuries, dating was performed by letters without numbers and the dating of renewal, conducted by Ahmed Katkhoda on the red minaret mosque an extension to this method, pl. being covered with a dome. $4^{\text {th }}$ inscription, it's a poetic inscription written by the Ottoman poet. Its content says that one of the leaders of Sultan Abdul Majeed supervised the foundation of Ottoman artillery building outside Tripoli. This building was called (Umeadi Castle). Perhaps the last line of the poem that says that the enemies went out of the castle three after three, stats that there was a rebellion against the ottoman authority and this leader quelled it by using the artillery battalion that settled in the castle. This inscription indicates the increased interest of the Ottoman Empire to establish defense foundations, which required the increase in expenditure, that expenditure came at the expense of other public, civilian, and religious foundations. this situation caused some drawbacks including the takeover of the military in the state with senior civil leadership positions [1].

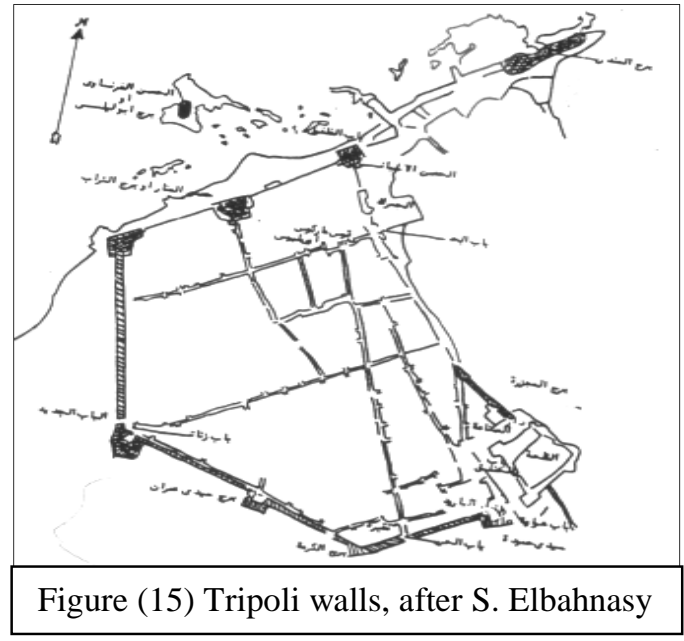

\& fig (2). In the Mamluk period, dating style was shifted from letters to numbers, and it has begun, in particular on coins [74]. Since this age, dating by numbers began to spread in Egypt and other Islamic countries. It spread in the Ottoman state with other methods, we find the dating for the renewal of Safr Dae to Bab Elbahr tower by numbers (1022 AH), pl. \& fig (1). It was perfected to use both calculation letters and numbers systems in the case of using poetry in Foundation inscriptions. This 
was clear in the inscriptions of Yousuf El mokney mosque and the Artillery building, and it is well known that the calculation letters is to replace letters with numbers, and this system was first used in Iran and then moved to other Islamic countries [75]. "Gamsheed ElKashi" explains the method of calculation as there are 28 letters, nine letters are individual (Alef: ta'a $=1: 9$ ) and nine letters score ten (Sad: Ya'a = 10:90), and nine letters hundred (qaf: Tha'a = 100: 900) and the last letter, Gheen $=1000$, and he said that the calculation letters in his time was famous [76]. $\mathbf{1}^{\text {st }} \& 2^{\text {nd }}$ inscriptions, (Bab Elbahr $1022 \mathrm{AH}$ ), the foundation and renewal of the red minaret mosque (1079-1089 AH) is relating to the first Ottoman era in Tripoli, a period which characterized by the presence of strong rulers (pashas) to the states, although the authority of the Ottomans was not beyond the limits of the coastal cities, and some of the insides [3]. It's clear that the princes and sultans were establishing mosques according to their religious and political role and motivated by their desire to perpetuate their names, and the rulers were the ideals to people who raced also to construct mosques [77]. Both the princes and the people were concerned with repairing and rebuilding the mosques [77]. These rulers competed in this matter because of the urgent need to it and they aimed also to gain the hearts of their people by religion [4]. $3^{\text {rd }}$ inscription, (Yousuf El mokney mosque $1123 \mathrm{AH}$ ) is in calculation letters style in the second part of the last verse as follow: Seemed $($ Bad'a $)=7,($ Amer $)=311,($ Sha'aban $)=$ 423, (yashany) $371=1112$ and it's less than the date written in numbers at the bottom of the text (1123 AH), with about eleven years. This date is in the beginning of Alqurmanli period, which was characterized by a partial independence from the Ottoman state, although Basha Alqurmanli should get the approval and consent of the Ottoman state when he takes the authority [3]. $4^{\text {th }}$ inscription is the inscription of artillery building (1268 AH/1851 AD) It belongs to the second Ottoman period. It is also dated with calculation letters and numbers together. The calculation letters is in the second half of the last line as follow Cornh $=281+$ Bala $=34+$ Oldy $=$ $51+$ Shulman $=421+$ Bootoobjee $=38+$ keshlasi $=501=1326$, and this date increased 58 years above the date of numbers written under the inscription which is $1268 \mathrm{AH}$. The reading of the word "Shulman" may be wrong and if the correct reading of the word is Shidmana $=396$, the total number will be 1301 , and it increases 33 years above the original date. In any case, rulers of the western Tripoli in this ottoman period were interested in enriching themselves, while the state was very worse economically. Some tribes revolted and there, sometimes, was insurgency among the members of the Janissaries. [3]. But Sultan Mahmud the second, who established this castle, could cancel the Janissaries corps after being corrupted. He founded, instead of them new military groups, according to the modern system. He brought European experts to train military bands, and the ottoman became committed to this supreme political plan after him [4]. The establishment of the castle in Tripoli in the period may explain these historical event and archaeological reality and became a witness about it.

\section{Conclusion}

Some results can be concluded from this research, which were published for the first time, these results are:

- The four inscriptions are considered documents based the interest and influence of the Ottomans on the West Tripoli, the documents and contractors of the foundations of Tripoli were moved to Istanbul or were lost during the Italian occupation.

- Three of the inscriptions proved that there was ottoman influence on Tripoli which transferred directly by the Ottomans themselves or indirectly through Tunisia, where a family from Safakus transferred these effects to it. 
- The research proves that the substance of the inscriptions (white marble) was brought from Ottoman Turkey and this is supported by the diversity of the methods of implementation, between prominent carving, coating or inlaying, which were performed on the hand of Ottoman craftsmen or those who learnt from them.

- Two famous ottoman scripts were used in performing these, they are Thuluth and Ta'aliq and Tughra'a drawing which is the Royal Ottoman signature.

- The decoration associated with the inscriptions has ottoman features, like Romi decoration, Lily flower, blooming flower, and the Ottoman flags.

- Two of the inscriptions were written in Turkish language using Arabic letters, and it's proved in this study that the use of Turkish language in West Tripoli preceded its use in Cairo by about half a century.

- Safar Dae, the governor of Tripoli, dubbed as "The Prince of Lowa" which is an ottoman title, and he associated it with another civilian title, such as (the owner of Glory) as a sign of the combination between military and civil authorities.

- Haij Ahmed, the founder and innovator of the Red Minaret mosque, occupied the job of Katkhoda" which indicates that he was the link between the Sultan and his senior staff, and the royal firmans were sent to the governor by him, it's an ottoman title for a job.

- Some Ottoman sultans have constructed, or ordered to be constructed some military foundations in West Tripoli, such as the Artillery building, that Sultan Abdul-Majeed the first ordered to be constructed, and one of his military leaders was the supervisor of its construction as an evidence of the state's interest of defensive aspects of that period.

- The purpose of the Ottoman inscriptions in West Tripoli wasn't for documentary purpose only but it was also decorative it has also variety of scripts, which amounted to a high degree of quality and excellence.

- The Ottoman has interested in fortifying and repairing the walls of West Tripoli, and restoring its walls .Bab Elbahr inscription indicates this interest which stems from the importance of its location on the sea from the defense side.

- Dating with calculation letters was used and became common in Ottoman Turkey foundations, or its affiliate states. It was used in two inscriptions out of the four inscriptionsof our study- and they used numbers.

- Writing style and types of scripts used in the inscriptions our study-prove that these inscriptions keep up with all the parts of the Ottoman Empire. We saw artistic development in two inscriptions from $11^{\text {th }} \mathrm{C}$. AH / $17 \mathrm{AD}$, and then blooming in the two centuries, 12-13 $A H /$ 18-19 AD.

- This research is considered an addition to the previous researches that studied the Ottoman influences on its subsidiaries states, concerning the inscriptions which are connected to different architectural foundations, such as the defensive and religious architecture.

\section{Endnotes}

(a) The inscription and its translation are published for the first time, and translated with the help of Dr. Naser Abdel-Rahim, the lecturer of Turkish language in Helwan University.

(b) The inscription is published for the first time, and the museum records noted that it was received from the red minaret mosque in Tripoli.

\section{References}

[1] El-Shenawy, A., (1986). Aldawla Alothmaniya dawla Islmiya mophtara alaiha, Vol.2, $1^{\text {st }}$ ed., Anglo, Egypt.

[2] Ziyada, N., Libya fi Al-Osoar alhaditha, Institute of Arabic studies and researches, university united Arabic nation,. Cairo

(c) The inscription is published for the first time.

(d) The inscription and its translation are published for the first time.

(e) Is confirmed by specialists in the Turkish language "Dr. Nasser Abdel Rahim Hussein"

[3] El-Balushi, A., (2007). Introduction tarikh Al-masgid fi Libya fi alahdin Alothmani wa Alqurmanly, World Islamic Call Society, Triboli, Libia.

[4] El-Shenawy, A., (1992). Aldawla AlOthmaniya dawla Islmiya mophtara alaiha, Vol.1, $2^{\text {nd }}$ ed., Anglo, Egypt. 
[5] Salim, A., (1981). Tarikh Al-maghrib fi Al-asr Al-islami, University youth foundation, Alexandria, Egypt.

[6] Messana, A., (1973)., Almemar Alislami fi Libya, translated by Hassanein A. Dar Algeel, Tripoli, Libya.

[7] Algarari, T., (2001). Al-Wathaeq AlOthmaniya fi Al-arshifat Al-arabia wa alturkia, Journal of Arabic Documents, The Dara of Almalik Abdul Aziz, Riyadh., KSA, pp: 387391.

[8] Aref, M.,(1897). Kholast Al-afkar fi fan almemar, Bulak publishing, Cairo, Egypt. \& Aljoma'a A., (1975), The marble monuments in Almawsel during the two eras of Atabeks and Elkhanids, unpublished Ph.D. Thesis, University of Cairo.

[9] Eliewa, H., (1988). Al-kitabat AlAthriya Al-Arabiya, Aljabalawey Publisher, Almansoura, Egypt.

[10] Abdel-Gawad, A., (1986.), AlEmara Alislamiya, fikr wa hadara, Anglo, Egypt.

[11] Ghalib, A., (1988), Mawsoat alemara alislamiya, Almatba'a Alarabeia, Beirut.

[12] Abdul-Latif L., (1978), Al-Edara fi Misr fi alasr Alothmani, Ain Shames univ., Cairo.

[13] Alraqed, A., (1972), Alghazw Alothmni le Misr wa nataegahu ala al-want al-arabi, foundation of the university youth of Alexandria, Egypt.

[14] Shared, K., (1976), Alrukham ewa estekhdamatehe abr altarikh, Cellulose library, Cairo, Egypt.

[15] Ramadan, H., (1981), Almaharib AlRukhamiya fi Qaherat Al-Mamalik Al-Bahriya, MA Thesis, Cairo University.

[16] Wathiqat Dawood Pasha bin Abdul Rahman, (972) No. 1176, endowments.

[17] El-Emary, A., (1978), Eadat Istekhdam Al-Rukham fi al-Aasr AlMamluki, Egyptian book organization \& Deyoji, S. (1964), Alzakharif Al-rukhamiya fi El-Mawsel,
Summer Magazine, Part 1, Vol. 2, pp: 161-176.

[18] Ibrahim, A., (1979), Al-Wathaeq fi khedmat Al-athar, Selselat Al-Derastat Al-Wathaeqiya, Derasat fi al-athar alislamiya, Publications of League of Arab countries, Cairo, Egypt.

[19] Al Jabarti, A., (without date), Ajaib Al-Athar fi El-Tarajum wa Al-AlAkhbar, 4 parts, Alanwar Muhammadiyah, Vol.1, Alanwar Almuhamadeia, Cairo.

[20] El Basha, H., (1956), Alfnun AlIslmiya wa Al-wazaef Ala Al-Athar Al-Arabiya, House of the Arab Renaissance Parts 1, 3, \& El emari, A., (1986), Zakharif shawahed alqobour fi Misr qabl Al-asr attuluny, Annal of Egyption archaeology organization Cairo, Vol. 4, private edition, pp: 1-68, Cairo.

[21] Abdul Wahab H., (1954), Tawqiaat alsuna ala athar Misr Al-Islamiya, Journal of the Egyptian Scientific Society, Vol. 16, pp: 533 - 5558

[22] Marzouq, M., (1987), Alfenun alzukhrufiya Al-Islmiya fi al-asr AlIslami, the Egyptian General Book Organization, Cairo, Egypt.

[23] El tabrizi,A., (1979), achieving Omar Yahya Kabbaoh ,Al-Wafi fi Al-Aroud wa Al-qawafi, thought House, $3^{\text {rd }}$ ed., Beirut. \& El Samman M., (1978) Fan Almusiqa fi El shear Al-Arabi, Central Organ of the books university and school, Egypt.

[24] El Basha, H., (1968), Alkhat, Alfan Al-Arabi Al-Asil, the Supreme Council for the Arts and Social Sciences, Cairo, Egypt.

[25] Marzouq M., (1953), Bain al-athar Al-Islamiya fi al-alam, Ramses, Alexandria \& Abdel-Razeq, A., (1981), Alwehda fin El fonoun AlIslamiya, Journal of the museum, Issue 3, pp: 35-43

[26] Khalifa, R., (1992), Gawaneb men Alhaiat Al-faniya fi alqahira AlOthmaniya, Study about artistic approaches and its effect on decorative architecture Faculty of 
arts, Special issue, 57, Cairo University.

[27] Hanash, A., (1998), Alkhat fi Alwathaeq Al-Othmaniya, Amman, Jordan.

[28] Samir El-Sayegh, Alfan Al-Islami, $1^{\text {st }}$ Ed., House of Knowledge, Beirut 1988.

[29] Dijkema, F., (1977), The ottoman historical monumental inscriptions in Edirne, leiden, E. J. Brill, Germany.

[30] El Basha, H., (1990), Madkhal ela Al-Athar Al-Islamiya, Dar Alnahda Alarabeia, Cairo, Egypt.

[31] Aslan Aba, O., (1987), Fonun AlTurk wa amaerhem, translated by Isa, A., Markaz Albahth Leltareekh wa Alfunon wa Athaqafa Aleslameya, Istanbul.

[32] Al-Tamimi, A., (1975), Fehras Aldafater Al-arabiya fi Algeria, Tunisia,

[33] El-Bahnasy, S., (2004), Trablus AlGharb, Derasat fi Alteraz Al-Memari wa Alfani, the prospects of Arab House, Cairo.

[34] El Basha, H., (1999), Alkhat, Alfan Al-Al-Arabi Al-Asil, The encyclopedia of architecture, monuments and Islamic Arts, Oriental papers, Vol. 3, p. 164-165.

[35] Al-qalqashandi, Sobh-El A'sha fi Senaat Al-Ensha, (1357 AH / 1938 AD). Vol. 3, The house of Egyptian books, Cairo.

[36] Al Kurdy, M., (1939), Tarikh Alkhat Al-Arabi Wa Adabeh, $1^{\text {st }}$ ed., the business printing press, Aljameaya Alarabeya Assaudia Lethaqafa wa Alfunon, $2^{\text {nd }}$ ed,1939, Riyadh.

[37] Ogorderman, M., (2001), Osloub fan Alkhat Al-Arabi lada Al-Othmanein, events of Arabic calligraphy days, Tunisian Academy of Sciences and Arts, Tunis.

[38] Safadi, Y.,(1978) Islamic Calligraphy, London.

[39] Oayiner, H., (1985), Hattat Osmanli Padisahlari, Antika, Nisan, Antika publisher, Istanbul.

[40] Albaba (Kael), Rouh Alkhat Al-Arabi, Home to millions of science, Beirut.

[41] Barakat, M., (1988), Derasa llkhat wa Al-Alqab wa Alwzaef men khelal Alnusus Altasisiya Albaqiya belamaer Al-Othmaniya bemadinat Alqahira, MA Thesis, Cairo University, Egypt.

[42] Saleh, L., (1984), Al-Turath Almemari Al-Islami fi Misr, Beirut.

[43] King Faisal Center for Research, (1984), Marad Alkhat AL-Arabi ,Qaat Alfan Al-Islami, Riyadh.

[44] Dawood, M., (1997) Alkitabat AlArabiya Ala Al-Athar Al-Islamiya month Alqarn Al-Awal hatta Alqarn athaniashar llhejra, Egyptian Renaissance Library, Cairo.

[45] El-Bahnasy,A., (1979), Gamaliat Alfan Al-Arabi, Alam Al-Marefa, Cairo.

[46] Oghorderman, M., (1976), Al-Atrak wa fan alkhat Al-Islami, Kitab AlAtrak fi Alfan Al-Islami, Istanbul.

[47] Joma'a, S. (1977) Al-Ebdaa Alfani fi Almakhtotat wa Alkutub Al-Islamiya, Islam Forum magazine, Issue 18, pp: 132-135.

[48] Barakat, M., (2007), Al-Islam wa Alfenun, Daerat Athaqafa walfunon, Shareqa, Alemarate \& El farouqi, I.(1981), Nazareyat Alfan Alislami,Almslem Almuaser Magazine, Vol. 25, Kuwait, pp: 1625.

[49] Eljabburi, Y., (1994), Alkhat wa Alkitaba fin Alhadara Al-Arabiya, The Islamic West house, Beirut.

[50] Shafie, F., (1994), Alemara AlArabiya fi Misr Al-Islamiya, Vol. 1, Asr Al-Wolat, the Egyptian General Book Organization.

[51] Maher, S. (1960), Turkish ceramic fi Misr alislameya, Almuktataf, Madkour Press, Cairo.

[52] Zaki, H., (1981), Fenun El-Islam, The leading Arab House, Beirut.

[53] Alqosairy E., (1987) Alzakharif Alnabatiya men Al-Arabesque ela Alraqsh Al-Arabi, Journal of the Kuwait Museum, Vol. 1, pp: 15- 131

[54] Khalifa R., (2001), Alfenun AlIslamiya fi Al-Asr Al-Othmani, Zahra Al-Shark. Cairo.

[55] Yassin A., (2009), Alzahra Almotafatiha motrakibat al-awraq ala dawe zakharif alfenun altatbiqiya 
almamlukiya fi Misr wa alsham, Journal of the Ages, Vol. 19, pp: 162209.

[56] Demand, S., (1982), Alfenun AlIslamiya, $3^{\text {rd }}$ ed., translated by Issa, A., Dar Alma'aref, $4^{\text {th }}$ ed ,Egypt.

[57] Yassin, A., (2000), Al-Ramziya AlDiniya fi Al-Zakhrapha Al-Islmiya, Study in the metaphysics of Islamic Art, Journal of the Faculty of Arts, Sohag University Vol. 23, No., 2, pp: 1 $-157$

[58] Hassan, Z., (1981) Fenun El-Islam, Dar Alread Alarabe ,Beirut.

[59] Al-Onsi, A., (Without date) AlDarari Allameat fi montakhabat Allughat, Ottoman language dictionary, Almaktaba Ala,lameya, Cairo.

[60] Abdel-Razek, A., (1987) Alwehda fin Elfonoun Al-Islamiya, Journal of the museum, $3^{\text {rd }}$ Issue, pp: 35- 43.

[61] Bayyti, F., (1994), Al-Talim fi AlIraq fi Al-Asr Al-Othmani, Journal of the Almawred, Baghdad, Vol. 22 (I) pp: 30- 46.

[62] El-Basha, H., (1988) Al-Alqab AlIslamiya fi Eltarikh wa Al-Wathaeq wa Al-Athar , $3^{\text {rd }}$ Ed., Dar Anahda Alarabeya,Cairo.

[63] Barakat, M., (2000), Al-Alqab wa Al-Wazaef Al-Othmaniya, dar gharib for printing and publishing, Cairo.

[64] El-safsafy, A., (1983) Al-Dawla AlOthmaniya wa Al-Welayat AlArabiya, Journal of Al-Dara, No. 4, Riyadh, pp: 80-98 \& Brockelmann, C. (1984), Tarikh Alshoub AlIslamiya, Beirut.

[65] El-Rashidi, A., (1980) The facility and happins by mentioning Al-Hajj principality, investigated by, Laila Abdul-Latif, Khanji library, Cairo.

[66] Sulaiman, A., (1979), Taasil ma warad fi Tarikh Al-Jabarty men Al-
Dakhil, House of Education, Dar Alma,aref publisher,Egypt

[67] Salheya, M. E., (1986-1987), Wathaeq Gadida an hamlat Sinan Pasha ela AlYemen 986 AH, Annals of the Faculty of Arts, Kuwait University, the message 42, pp: 19-86.

[68] Altamagharwi, A., (1929), AlNaphahat Al-Miskiya fi Al-Sefarat Al-Turkiya, Paul Kithr, Paris.

[69] Alzawi, A., (1954), Tarikh Al-Fath Al-Araby fi Libya, Almaktaba Alarabeya, Cairo.

[70] El-Shihabi, Q., (1995), Mogam Alqab Arbab Al-Sultan fi El-Dowal Al-Islamiya, Ministry of Culture, Damascus 1995.

[71] Ogli, S., (1982), Resimlimoifli Tturk edebiyati Tarihi, 2cilt, Istanbul.

[72] El-Bakry, A., (1857), Al Mughrab fe Thekr Belad Afrecia wa Al-maghreb Almasalek Walmamalek, Deslan publisher, Algeria.

[73] El Zarkashi, M., (1996), Eilam Asajed Beahkam Al-masajed, $4^{\text {th }}$ Ed., revised by El Maraghy, Almagles Alaela Lelsheoun Aleslameya, Cairo.

[74] El Nabrawy, R., (1996), Al-nokoud Al-eslameia, Asr Dawlat Al-mamalik Al-Jarakesa, $2^{\text {nd }}$ ed., Markez Alhadarh Alarabeya lele'lam wa Alnashr ,Cairo.

[75] Sameh, K., (1991), Al-emara Aleslameia fe Misr, General Book Organization, Cairo.

[76] El Kashi, J., Muftah Al-hesab, House of Arab Book, revised by Demerdash, A. \& Hanafi M., Dar Alkateb Alaraby lelteba'a wa Alnasher, Cairo

[77] Abdul Sattar, M., (2005) Nazareyat Al-wazefeia Bel-amaer Adeneya Almamlukeia Al-bakeya Bemadenat Alkahera , Dar alwafa'a ledunia ateba'a wa alnasher, Alex. 